

Serniak Oleh Ihorovych,

PhD in Public Administration, Associate Professor at the Department of Public Management and Administration of the Ivano-Frankivsk National Technical University of Oil and Gas, 76019, Ivano-Frankivsk, Str. Karpatska, 15; oleh sernyak@ukr.net; +38 (066) 246-90-45

ORCID: 0000-0002-8935-3253

\title{
“ДЕМОНОПОЛІЗАЦІЯ” ВИЩОї ОСВІТИ ЯК СКЛАДОВА НАЦІОНАЛЬНОЇ БЕЗПЕКИ УКРАЇНИ (АРХЕТИПНИЙ ПІДХІД)
}

Анотація. Розглянуто проміжні результати реформування вищої освіти в Україні відповідно до профільного закону. Наведено приклади якісних змін щодо зменшення навантаження викладачів, заборони суміщення адміністративних посад в університетах, системи рівнів освіти, підвищення прозорості діяльності вузів і зростання прав студентського самоврядування. Водночас виокремлено кілька архетипів, які заважають впровадженню ефективних освітніх змін і які становлять потенційну загрозу національній безпеці держави. Вони усі зводяться до поняття “монополізації” вищої освіти як концентрації ключових повноважень у цій сфері, зокрема щодо забезпечення якості освіти, в руках однієї (міністерства) чи кількох пов'язаних між собою державних інституцій (міністерство, НАЗЯВО, Державна служба якості освіти). 
Такими архетипами є забюрократизованість та негнучкість університетів України, що не дозволяє їм конкурувати на рівних з освітніми закладами європейських країн; їх організаційна залежність від патерналізму 3 боку міністерства та інших інституцій влади, з одного боку, та надмірний патерналізм і небажання держави делегувати повноваження щодо розвитку реальної університетської автономії, з іншого; неспроможність державних інституцій в освіті працювати за принципом проектного офісу з переходом виключно до координуючої та моніторингової функцій; відмова з боку університетського середовища і міністерства визнавати громадськість в особі студентів, їх батьків і роботодавців як рівноправних партнерів у процесах управління якістю освіти.

Для зміни останнього архетипу, який окремі науковці називають “смисловим ядром” всієї моделі вищої освіти, запропоновано створити в Україні інститут незалежних освітніх аудиторів як механізм безпосереднього впливу громадськості та бенефіціарів на процеси забезпечення якості вищої освіти. Розглянуто мету такого аудиту, його переваги для університетів, вимоги до професійного рівня самих аудиторів, організаційні аспекти й ризики функціонування інституту незалежних освітніх аудиторів.

Ключові слова: публічне управління, вища освіта, “демонополізація” вищої освіти, забезпечення якості вищої освіти, національна безпека, архетип, незалежний освітній аудитор.

\section{“ДЕМОНОПОЛИЗАЦИЯ” ВЫСШЕГО ОБРАЗОВАНИЯ КАК СОСТАВЛЯЮЩАЯ НАЦИОНАЛЬНОЙ БЕЗОПАСНОСТИ УКРАИНЫ (АРХЕТИПНЫЙ ПОДХОД)}

Аннотация. Рассмотрены промежуточные результаты реформирования высшего образования в Украине в соответствии с профильным законом. Приведены примеры качественных изменений по уменьшению нагрузки преподавателей, запрету совмещения административных должностей в университетах, повышению прозрачности деятельности вузов и росту прав студенческого самоуправления. В то же время выделены несколько архетипов, которые мешают внедрению эффективных образовательных изменений и которые представляют потенциальную угрозу национальной безопасности государства. Они все сводятся к понятию “монополизации” высшего образования как концентрации ключевых полномочий в этой сфере, в частности по обеспечению качества образования, в руках одного (министерства) или нескольких связанных между собой государственных институтов (министерство, НАЗЯВО, Государственная служба качества образования).

Такими архетипами являются забюрократизированность и негибкость университетов Украины, что не позволяет им конкурировать на равных с образовательными учреждениями европейских стран; их организационная зависимость от патернализма со стороны министерства и других институтов власти, с одной стороны, и чрезмерный патернализм и нежелание государства делегировать полномочия по развитию реальной университетской ав- 
тономии, з другой; несостоятельность высших государственных институтов работать по принципу проектного офиса с переходом исключительно к координирующей и мониторинговой функции; отказ со стороны университетской среды и министерства признавать общественность в лице студентов, их родителей и работодателей как равноправных партнеров в процессах управления качеством образования.

Для изменения последнего архетипа, который отдельные ученые называют “смысловым ядром” всей модели высшего образования, предложено создать в Украине институт независимых образовательных аудиторов как механизм непосредственного влияния общественности и бенефициаров на процессы обеспечения качества высшего образования. Рассмотрены цель такого аудита, его преимущества для университетов, требования к профессиональному уровню самих аудиторов, организационные аспекты и риски функционирования института независимых образовательных аудиторов.

Ключевые слова: государственное управление, высшее образование, “демонополизация” высшего образования, обеспечение качества высшего образования, национальная безопасность, архетип, независимый образовательный аудитор.

\section{"DEMONOPOLIZATION" OF HIGHER EDUCATION AS A COMPONENT OF NATIONAL SECURITY OF UKRAINE (ARCHETYPAL APPROACH)}

Abstract. The article deals with the intermediate results of the reform of higher education in Ukraine in accordance with the standard law. Examples of qualitative changes to reduce the burden on teachers, the prohibition of the combination of administrative positions at universities, transparency of the universities' activities and the growth of student self-government rights are given. At the same time, there are several archetypes that impede the implementation of effective educational changes and which pose a potential threat to the national security of the state. All of them are reduced to the concept of "monopolization" of higher education as the concentration of key competences in this area, in particular in terms of ensuring the quality of education, in the hands of one (the ministry) or several interrelated public institutions (ministry, national quality agency, Public service of quality of education).

Such archetypes are bureaucracy and inflexibility of the Ukrainian universities, which prevents them from competing on an equal footing with educational institutions of European countries; their organizational dependence on paternalism by the ministry and other institutions of power, on the one hand, and the excessive paternalism and reluctance of the state to delegate authority over the development of real university autonomy, on the other; the failure of public institutions in education to work on the principle of a project office with the transition to coordinating and monitoring functions; the refusal of the university environment and the ministry to recognize the public in the person of students, their parents and employers as equal partners in the processes of quality education management. 
In order to change the last archetype that some scholars call the "semantic core" of the whole model of higher education, it is proposed to create in Ukraine an institute of independent educational auditors as a mechanism of direct influence of the public and beneficiaries on the processes of higher education quality ensuring. The purpose of such an audit, its advantages for universities, the requirements to the professional level of the auditors themselves, organizational aspects and risks of the functioning of the institute of independent educational auditors are considered.

Keywords: public administration, higher education, "demonopolization" of higher education, quality assurance in higher education, national security, archetype, independent educational auditor.

Постановка проблеми. Протягом останніх п'яти років національна безпека визначає порядок денний внутрішньої та зовнішньої політики України. До неї прикуті зусилля найвищих інституцій публічної влади, громадськості та ЗМІ. Для забезпечення обороноздатності держави та безпеки громадян Кабінетом Міністрів України передбачено 212 млрд грн (5,4 \% ВВП) на 2019 рік, що на 33,3 млрд грн перевищує видатки попереднього року. Проте система національної безпеки України досі слабка перед численними викликами і зумовлено це тим, що вона охоплює не лише оборонну сферу та протидію зовнішнім загрозам, але й зачіпає усі життєво важливі інтереси людини, суспільства і держави, реалізація яких забезпечує державний суверенітет України, іiі прогресивний демократичний розвиток, а також безпечні умови життєдіяльності та добробут її громадян.

Однією зі сфер, які мають опосередкований вплив на національну безпеку держави, є освіта загалом і вища освіта зокрема. 3 одного боку, завдяки освітнім інституціям форму- ється кадровий потенціал сфери безпеки й оборони, а 3 іншого - рівень освіченості визначає громадянську та політичну активність, готовність ставити національні інтереси вище особистих. Тому з метою посилення національної безпеки України сьогодні важливо активізувати освітні реформаційні процеси, насамперед у сфері вищої освіти, науково переосмислити патерналістський архетип міністерства й остаточно перейти від централізованого управління до університетської автономії, громадського моніторингу й контролю за цією сферою.

Аналіз останніх досліджень та публікацій. Розвитку освіти як складової національної безпеки України присвячено аналітичну доповідь Національного інституту стратегічних досліджень “Безпекові виміри освітньої політики: світовий досвід і українські реаліі" (2017). У дослідженні, зокрема, висвітлено питання формування безпекових критеріїв в освіті, вирішення основних завдань реформування освітньо-наукової сфери, виявлення та подолання проблемних зон в освітній системі, нейтралізації 
негативного впливу російської військової агресії на систему освіти [1]. Також проблематиці впливу освіти на посилення національної безпеки держави в різний період приділяли увагу С. Красняков, Е. Лузік, Т. Лукіна, I. Мусієнко, О. Тарасенко, Л. Хоменко-Семенова, Л. Чупрій та інші науковці. Проте питання прямої залежності між архетипами в публічному управлінні, децентралізаційними та дерегуляційними реформами вищої освіти в Україні та сферою національної безпеки дотепер не було предметом наукових досліджень.

Мета статті - схарактеризувати результати реформування системи вищої освіти в Україні після запровадження закону "Про вищу освіту”; окреслити основні архетипи, що заважають якісним змінам системи вищої освіти; запропонувати шляхи “демонополізаціï” вищої освіти та підвищення ролі громадськості та бенефіціарів у забезпеченні якості вищої освіти.

Виклад основного матеріалу. Ухвалення Закону України "Про вищу освіту” від 01.07.2014 р. ознаменувало кілька революційних системних змін у сфері вищої освіти. Насамперед, це - академічна та фінансова автономія навчального закладу, передача значної частини повноважень у сфері забезпечення якості вищої освіти незалежній інституції “Національне агентство із забезпечення якості вищої освіти (НАЗЯВО)”, припинення узурпації влади в університетах, боротьба 3 науковим плагіатом на рівні вишу й інші важливі нововведення [2]. Проте від дати ухвалення Закону України “Про вищу освіту” минуло понад 4,5 роки і за цей час реальні зміни відбулися хіба щодо зменшення навантаження викладачів, заборони суміщення адміністративних посад в університетах, системи рівнів освіти, підвищення прозорості діяльності вузів i зростання прав студентського самоврядування. А персональний склад НАЗЯВО сформувався наприкінці 2018 року та лише з другої спроби.

Ситуація з імплементацією положень закону щодо дебюрократизації та децентралізації повноважень на рівень університетів насторожила навіть керівництво Міністерство освіти і науки України. Так, міністр освіти i науки України Лілія Гриневич під час засідання розширеної Колегії МОН 26.01.2018 року підкреслила, що “широка автономія університетів посилила розрив між провідними вишами й “іншими”. Перші скористалися нагодою - запровадили нові освітні програми, залучили роботодавців, увійшли в міжнародні проекти, навчилися розумно планувати освітній процес, зайнялися комерціалізацією власних наукових досліджень, намагаючись створювати конкуренцію на ринку освітніх послуг. "Інші" - капсулювалися у своїй неспроможності ефективного управління" [3]. У результаті в профільному міністерстві заговорили про застарілість закону та потребу внесення до нього змін.

Проміжний аналіз першої “п’ятирічки” реформування вищої освіти в Україні дозволяє виокремити кілька архетипів, які заважають впровадженню ефективних освітніх змін $\mathrm{i}$ які становлять потенційну загрозу національній безпеці держави. Їх усіх можна звести до поняття "монополі- 
зації” вищої освіти в Україні в особі міністерства й інших державних інституцій як концентрації ключових повноважень у цій сфері, зокрема щодо забезпечення якості освіти, в руках однієї (міністерства) чи кількох пов'язаних між собою державних інституцій (міністерство, НАЗЯВО, Державна служба якості освіти).

Перший архетип - університети в Україні - занадто забюрократизовані та негнучкі, що не дозволяє їм конкурувати на рівних з освітніми закладами європейських країн. I тут складно сперечатися, адже за результатами дослідження аналітичного центру CEDOS у 2015-2016 навчальному році лише в Польщі навчалося понад 30 тис. українських студентів, а загалом близько 70 тис. наших співгромадян у цей період навчалося закордоном [4]. Як наслідок, конкуренція між українськими вузами за студентів часто переходить у площину конкуренції між “потрібними зв'язками” в міністерстві при розподілі державного замовлення чи проходженні ліцензійно-акредитаційних процедур. Оскільки новий закон ці “схеми” не зруйнував, то змінюватися кардинально вузи здебільшого не будуть.

Другий - вітчизняні вузи потребують патерналізму з боку міністерства та інших інституцій влади. Менеджмент університетів є фаховим у науковій і педагогічній площині, проте часто непрофесійний в управлінській сфері. Тому організувати процеси чи створити нормативне поле всередині вузу стає майже неймовірним завданням. Натомість діяти в межах інструкцій чи директив “згори” і зручніше, і простіше. Водночас, і $\mathrm{MOH} \mathrm{не} \mathrm{готове} \mathrm{повною} \mathrm{мірою} \mathrm{ви-}$ конувати вимоги закону "Про вищу освіту" в частині передання повноважень на рівень вузів, зокрема щодо права визнання іноземних дипломів і ступенів, права присудження наукових ступенів, права вузів видавати власні дипломи поряд із державними. Така “живучість” архетипу патерналізму багатьма науковцями пояснюється підсвідомим тяжінням до візантійської традиції та більшою мірою східною, ніж західною, ментальністю українців. Але на нашу думку, він зумовлений виключно природою людини, небажанням виходити з зони комфорту, ініціювати рішення та брати відповідальність за їх виконання.

Третій архетип - державні інституції погано працюють за принципом проектного офісу, а тому очікувати повної “демонополізації” вищої освіти, що тягне за собою масове скорочення державних службовців і перехід до координуючої та моніторингової функцій, у ближчому майбутньому не варто. Адже у суспільстві, де освіта, наука та медицина е майже недоторканими сферами, такий крок може тлумачитися як "руйнування", диверсія та підрив національної безпеки. Хоча насправді саме неякісний рівень послуг у цих сфеpax i $є$ основною загрозою нацбезпеці держави.

Четвертий архетип - для міністерства та вітчизняних вузів громадськість може бути залучена до процесів у вищій освіті лише як абітурієнти та як роботодавці. Моніторити та впливати на якість вищої освіти компетентні лише МОН, державні та квазідержавні (НАЗЯВО) інститу- 
ції. Цей архетип досить складно переосмислити суспільною свідомістю. 3 одного боку, абітурієнти, студенти, ї батьки, роботодавці та громадські організації не вірять у власні сили брати участь у забезпеченні якості вищої освіти та реально впливати на те, що відбувається у вишах, з іншого - професорсько-викладацьке й університетське середовище не готове спілкуватися з бенефіціарами освітніх послуг на партнерських засадах.

На нашу думку, найскладнішим архетипним явищем у вищій освіті, який потребує кардинальних i piшучих змін у напрямку “демонополізації”, є залучення громадськості до управління якістю вищої освіти. Вітчизняний науковець Ю. Федорченко називає цю сферу “смисловим ядром” всієї моделі вищої освіти та визначає важливість ii реформування [5]. Згідно Закону України "Про вищу освіту" функцію забезпечення якості вищої освіти МОН мало би передати НАЗЯВО. Але, схоже, що у спроможність цієї інституції забезпечувати якість вищої освіти в Україні не вірили й самі розробники закону, а тому вирішили іiі підстрахувати галузевими експертними радами та звичною для будь-якої бюрократичної організації структурою, яка насправді реально здійснюватиме усю роботу установи із забезпечення якості, - секретаріатом. Окрім того, для стримування надмірної самостійності Нацагентсва найважливіші його рішення - щодо формування вимог до системи забезпечення якості вищої освіти, розроблення положення про акредитацію освітніх програм, розроблення вимог до рівня науко- вої кваліфікації осіб, які здобувають наукові ступені, і порядку їх присудження спеціалізованими вченими радами вищих навчальних закладів (наукових установ) - набуватимуть юридичної сили лише після затвердження Міністерством освіти і науки України.

Отже, ситуація із забезпеченням якості вищої освіти в Україні залишається вкрай тривожною. 3 одного боку, держава не має наміру втрачати монопольний контроль над сферою ліцензування та акредитації ВНЗ й присудження наукових ступенів, а 3 іншого - відплив українських студентів закордон і брак кваліфікованих кадрів у різних галузях економіки України спонукає шукати інноваційні шляхи забезпечення якості вищої освіти. Одним із них є створення інституту незалежних освітніх аудиторів.

Метою незалежного освітнього аудиту є підтвердження відповідності рівня якості вищої освіти у ВНЗ встановленим нормативним вимогам, що є тотожним проходженню процедури ліцензування й акредитації, та обов'язково вироблення практичних рекомендацій щодо підвищення якості вищої освіти. Відмінність незалежного освітнього аудиту від традиційної акредитації полягає у праві керівництва навчального закладу самостійно вирішувати, що робити зі звітом:

- у разі позитивного висновку опублікувати його, а студенти та роботодавці вже самі вирішать, чи довіряти цьому висновку й аудитору;

- у разі негативного висновку удосконалити невідповідні стандартам складові освітньої діяльності 
ВНЗ і потім повторно скористатися послугами незалежного освітнього аудитора.

Виходячи із суті незалежного освітнього аудиту як експертизи якості вищої освіти, що здійснюється добровільно за замовленням вищих навчальних закладів на основі укладеного договору $з$ використанням заздалегідь обумовлених видів, часу і форм експертизи при дотриманні умов повної конфіденційності отриманих результатів, можна виокремити такі основні його переваги для вищих навчальних закладів:

- можливість отримати незалежну оцінку якості освітніх програм i підготовки фахівців, уникнення директивного впливу державних інституцій на діяльність ВНЗ;

• незалежний освітній аудит не порушує незалежність ВНЗ і спонукає освітні організації до розроблення й ефективного функціонування власних внутрішніх систем оцінювання та забезпечення якості вищої освіти;

- переведення процедур ліцензування й акредитації з площини забезпечення формальних кількісних показників у площину реального поліпшення якості навчання, що є важливим фактором підвищення конкурентоспроможності ВНЗ на ринку освітніх послуг;

- незалежний освітній аудит дає змогу публічно заявити про високий рівень якості підготовки фахівців у даному ВНЗ, завоювати та зміцнити позиції освітньої організації на міжнародному ринку освітніх послуг, поліпшити працевлаштування випускників.

Функціонування інституту незалежних освітніх аудиторів відповідає положенням “Стандартів і рекомендацій щодо забезпечення якості в Європейському просторі вищої освіти" від 2015 року, зокрема, в частині повноважень групи незалежних (зовнішніх) експертів, яка включає представника (представників) від студентів, та враховує різні точки зору стейкхолдерів, включаючи навчальні заклади, викладачів, студентів i роботодавців/професіоналів-практиків [6].

Запровадження інституту незалежних освітніх аудиторів висуває жорсткі вимоги до професійного рівня самих аудиторів. Вони повинні мати необхідні навички та компетенції для виконання своїх завдань, проходити належне навчання та постійно підвищувати свій професійний рівень. Звичайно, до незалежного освітнього аудиту можна залучати міжнародних експертів, але було б ефективніше використати їхні знання та досвід для підготовки незалежних освітніх аудиторів в Україні та розроблення стандартів проведення такого аудиту.

Діяльність незалежних освітніх аудиторів має підлягати обов'язковій сертифікації. Згідно 3 п. 1 ст. 23 Закону України "Про вищу освіту" незалежні установи з оцінювання та забезпечення якості акредитуються НАЗЯВО [7]. Це автоматично гарантує сертифікацію усіх осіб, які працюють в даній організації. Проте, на наш погляд, більш ефективною та об'єктивною є процедура сертифікації, прийнята в аудиторській діяльності. Сертифікація аудиторів проводиться шляхом складання письмового кваліфікаційного іспиту за програмою, затвердженою Ау- 
диторською палатою України, яка є незалежною неприбутковою організацією. Термін чинності сертифіката не може перевищувати п'яти років i може бути продовжений через п'ять років за підсумками контрольного тестування за фахом у порядку, встановленому Аудиторською палатою України [8].

Відповідно сертифікацію незалежних освітніх аудиторів має проводити неприбуткова громадська організація незалежних освітніх аудиторів України за власними програмами первинної та повторної сертифікації, які базуватимуться на найкращому зарубіжному досвіді. Однак, перед створенням такої організації доцільно здійснити відбір і підготовку хоча би десяти незалежних освітніх аудиторів за грантові кошти і під контролем міжнародних установ із забезпечення якості вищої освіти, які в подальшому стануть засновниками громадської організації.

Дана громадська організація має самостійно визначати вимоги до освіти та рівня фахової підготовки незалежних освітніх аудиторів, організовувати їх навчання та регулярне підвищення кваліфікації. Вона здійснюватиме контроль за діяльністю усіх незалежних освітніх аудиторів щодо дотримання ними стандартів діяльності та професійної етики, а у випадку порушення цих вимог позбавлятиме конкретних осіб права здійснювати аудиторську діяльність. Так, треба бути свідомими щодо можливих ризиків, пов'язаних із завищенням вартості послуг незалежних освітніх аудиторів, надмірним формалізмом процесу аудиту чи перспективою перетворення їх на маріонетки великих університетів. Але усі ці явища з боку державних інституцій ми маємо змогу спостерігати вже сьогодні і навіть у більших масштабах. Тому боротися 3 потенційними загрозами варто від початку створення інституту освітніх аудиторів, розробляючи прозорі та зрозумілі для всіх учасників ринку правила гри, постійно підвищуючи вимоги до аудиторів i водночас престижність їхньої праці, залучаючи до цього процесу максимально можливу кількість зацікавлених осіб, зокрема, міжнародні освітні інституції, 3МІ та громадські організації. Лише в такому випадку освітній аудит стане дійсно незалежним механізмом громадського контролю за якістю вищої освіти в Україні.

Зрозуміло, що запровадження інституту незалежних освітніх аудиторів і “демонополізація” вищої освіти загалом, зустріне чимало противників як серед чиновників Міністерства освіти і науки України, так і серед недобросовісних керівників навчальних закладів, які звикли йти протоптаним роками корупційним шляхом. Але зацікавлених у реалізації цієї ідеї осіб і організацій в рази більше. Це - і прогресивні ВНЗ, які вже сьогодні активно дбають про якість освіти (зокрема, Національний університет “Києво-Могилянська академія", Національний університет "Львівська політехніка”, Український католицький університет, Національний університет “Острозька академія” й інші), і громадські організації та рухи (Чесно, Опора, Центр протидії корупції й інші), і студенти, і академічна спільнота, і бізнес-середовище, і загалом держава Україна. 
Запровадження інституту незалежних освітніх аудиторів передбачає проведення досить великої роботи. Перший етап полягає в підготовці й ухваленні Закону України "Про незалежний освітній аудит”. У рамках цієї адвокаційної кампанії передбачається також розроблення концепції функціонування інституту незалежних освітніх аудиторів на основі Стандартів і рекомендацій щодо забезпечення якості в Європейському просторі вищої освіти, проведення інформаційно-роз'яснювальної кампанії щодо необхідності підвищення ВНЗ якості освіти та щодо створення образу освітнього аудитора як партнера цього процесу, розроблення процедур професійної підготовки освітніх аудиторів і методики проведення ними незалежного освітнього аудиту.

Таким чином, незалежний освітній аудит - не панацея від усіх проблем вищої освіти. Але це впевнений крок до прозорості дотепер закритих від громадськості процесів ліцензування й акредитації, а також до свободи вибору навчальними закладами суб'єктів освітнього аудиту і як наслідок - втрати монополії держави над згаданими процесами. Активне залучення громадськості, професіоналів і міжнародних експертів до підвищення результативності освітніх послуг гарантує в середньостроковій перспективі покращення якості освіти й науки в Україні, а через неї і посилення національної безпеки України.

Висновки і перспективи подальших досліджень. Архетипи публічного управління присутні в усіх його сферах, зокрема і в управлінні вищою освітою. Йдеться про надмірну бюрократизацію процесів, централізованість ухвалення рішень, "монополізацію” найважливіших напрямків діяльності. Це зумовлено як самою природою управлінської діяльності, так і відсутністю ініціативності, інноваційності, взаємної довіри між особами, які беруть безпосередню участь в освітніх процесах, та бенефіціарами освітніх послуг.

Держава продовжує зберігати монопольний контроль над сферою забезпечення якості вищої освіти, але відплив українських студентів закордон і брак кваліфікованих кадрів у різних галузях економіки України свідчить про неефективність цього механізму. Водночас, ці негативні тенденції становлять безпосередню загрозу національній безпеці держави.

Для здійснення кардинальних і рішучих змін у напрямку “демонополізації” вищої освіти необхідне системне залучення громадськості до управління якістю вищої освіти. Таким механізмом може стати створення інституту незалежних освітніх аудиторів, який займатиметься підтвердженням відповідності рівня якості вищої освіти у ВНЗ встановленим нормативним вимогам, що $є$ тотожним проходженню процедури ліцензування й акредитації, 3 обов'язковим виробленням практичних рекомендацій щодо підвищення якості вищої освіти в конкретному виші.

Представляючи і діючи в інтересах громадськості та бенефіціарів освітніх послуг незалежні освітні аудитори можуть як підвищити конкурентоспроможність вітчизняної 
освіти, так і в короткий час покращити якість освітніх послуг відповідно до суспільних запитів і світових освітніх тенденцій. Будучи громадським інститутом, володіючи природною інституційною гнучкістю та маючи мінімальну політичну волю з боку владних інституцій, незалежні освітні аудитори можуть змінити організаційні архетипи системи вищої освіти, зробити їі більш відкритою, адаптивною та результативною.

У разі успішної реалізації цих нововведень вдасться позбутися монополії держави над процесами ліцензування й акредитації та запустити механізм професійного громадського контролю за цією сферою, що спонукатиме самі вузи дбати про постійне підвищення якості вищої освіти, оскільки іншого шляху (тіньового, корупційного) для існування в них не буде. Це буде революційно-еволюційний шлях розвитку вищої освіти України, який нівелює ключові внутрішні загрози національній безпеці держави.

\section{СПИСОК ВИКОРИСТАНИХ ДЖЕРЕЛ}

1. Безпекові виміри освітньої політики: світовий досвід і українські реалії: аналітична доповідь [Електронний ресурс] / Т. В. Черненко, М. М. Карпенко, В. С. Лозовий, С. О. Зубченко, А. Ю. Іщенко // Нац. ін-т стратегічних досліджень. 2017. Режим доступу : http://www. niss.gov.ua/content/articles/files/ Osvita_Bezpeka-40c41.pdf.

2. Шамайда T. 16 революційних змін у вищій освіті: Новий закон почав діяти [Електронний ресурс] /
T. Шамайда // Незалежне Інтернет-видання "TEXTY.ORG.UA". 2014. Режим доступу : http://texty. org.ua/pg/article/textynewseditor/ read/55679/16_revolucijnyh zmin_u_vyshhij_osviti_Novyj

3. Лілія Гриневич: Прийнятий у 2014му ЗУ “Про вищу освіту” запровадив багато потрібних новацій, але сьогодні він уже застарів та потребує змін // М-во освіти і науки України : офіц. сайт. 2018. Режим доступу: https://mon.gov.ua/ua/news/ liliya-grinevich-prijnyatij-u-2014mu-zu-pro-vishu-osvitu-zaprovadivbagato-potribnih-novacij-ale-sogodnivin-uzhe-zastariv-ta-potrebuyezmin

4. Стадний $\epsilon$. Українські студенти закордоном: факти та стереотипи [Електронний ресурс] / С. Стадний // Аналітичний центр CEDOS. 2017. Режим доступу : https:// cedos.org.ua/uk/articles/ukrainskistudenty-za-kordonom-fakty-tastereotypy

5. Федорченко Ю. Чи треба радикально міняти закон “Про вищу освіту”? [Електронний ресурс] / Ю. Федорченко // Освіта.ua. 2018. Режим доступу : https://osvita.ua/ vnz/reform/59677/

6. Стандарти і рекомендації щодо забезпечення якості в Свропейському просторі вищої освіти (ESG) / пер. 3 англ. К. : ТОВ “ЦС”, 2015. 32 с.

7. Про вищу освіту : Закон України [Електронний ресурс] / Верховна Рада України ; від 01.07.2014 р. № 1556-VII. Режим доступу : http:/ / zakon4.rada.gov.ua/laws/show/155618

8. Про аудиторську діяльність : Закон України [Електронний ресурс] / Верховна Рада України ; від 22.04.1993 p. № 3125-XII. Режим доступу : http://zakon4.rada.gov.ua/ laws/show/3125-12 


\section{REFERENCES}

1. Chernenko T. V., Karpenko M. M., Lozovyi V. S., Zubchenko S. O., \& Ishchenko A.Yu. (2017). Bezpekovi vymiry osvitnoi polityky: svitovyi dosvid i ukrainski realii [Security Measures of Educational Policy: World Experience and Ukrainian Realities]. Natsionalnyi instytut stratehichnykh doslidjen - $\mathrm{Na}$ tional Institute for Strategic Studies. Retrieved from http://www.niss.gov. ua/content/articles/files/Osvita_ Bezpeka-40c41.pdf [in Ukrainian].

2. Shamaida T. (2014). 16 revolyutsiinykh zmin u vyshchiy osviti: Novyi zakon pochav diyaty [16 Revolutionary Changes in Higher Education: The New Law Began to Operate]. Nezalejne Internet-vydannia "TEXTY. ORG.UA" - Independent Online Edition "TEXTY.ORG.UA”. Retrieved from http://texty.org.ua/pg/article/textynewseditor/read/55679/16_revolucijnyh_zmin_u_vyshhij_osviti__Novyj [in Ukrainian].

3. Liliia Hrynevych: Pryiniatyi u 2014mu ZU "Pro vyshchu osvitu" zaprovadyv bahato potribnykh novatsii, ale sohodni vin uje zastariv i potrebue zmin [Lilia Hrynevych: In 2014, the Law on Higher Education Introduced Many Necessary Innovations, but Today It is Outdated and Needs to be Changed]. (2018). Ministerstoo osvity i nauky Ukrainy: ofitsiinyi sait Ministry of Education and Science of Ukraine: official site. Retrieved from https://mon.gov.ua/ua/news/ liliya-grinevich-prijnyatij-u-2014-muzu-pro-vishu-osvitu-zaprovadiv-bagato-potribnih-novacij-ale-sogodni- vin-uzhe-zastariv-ta-potrebuye-zmin [in Ukrainian].

4. Stadnyi Ye. (2017). Ukrainski studenty zakordonom: fakty ta stereotypy [Ukrainian Students Abroad: Facts and Stereotypes]. Analitychnyi tsentr CEDOS - CEDOS Think Tank. Retrieved from https://cedos.org. ua/uk/articles/ukrainski-studentyza-kordonom-fakty-ta-stereotypy [in Ukrainian].

5. Fedorchenko Yu. (2018). Chy treba radykalno miniaty zakon "Pro vyshchu osvitu"? [Do It Need to Radically Change the Law "On Higher Education”?]. Osvita.ua - Education.ua. Retrieved from https://osvita.ua/vnz/ reform/59677/ [in Ukrainian].

6. Standarty $i$ rekomendatsii shchodo zabezpechennia yakosti v Yevropeiskomu prostori oyshchoi osvity (ESG) [Standards and Recommendations for Quality Assurance in the European Higher Education Area (ESG)]. (2015). Kyiv: TOV "TsS" [in Ukrainian].

7. Zakon Ukrainy Pro vyshchu osvitu : pryiniatyi 1 lyp. 2014 roku № 1556VII [Law of Ukraine on higher education from July 1 2014, № 1556-VII]. Verkhowna Rada Ukrainy - Verkhovna Rada of Ukraine. Retrieved from http://zakon4.rada.gov.ua/laws / show/1556-18 [in Ukrainian].

8. Zakon Ukrainy Pro audytorsku diialnist : pryiniatyi 22 kvit. 1993 roku № 3125-XII [Law of Ukraine on audit activity from April 22 1993, № 3125-XII]. Verkhovna Rada Ukrainy - Verkhoona Rada of Ukraine. Retrieved from http://zakon4.rada. gov.ua/laws/show/3125-12 [in Ukrainian]. 